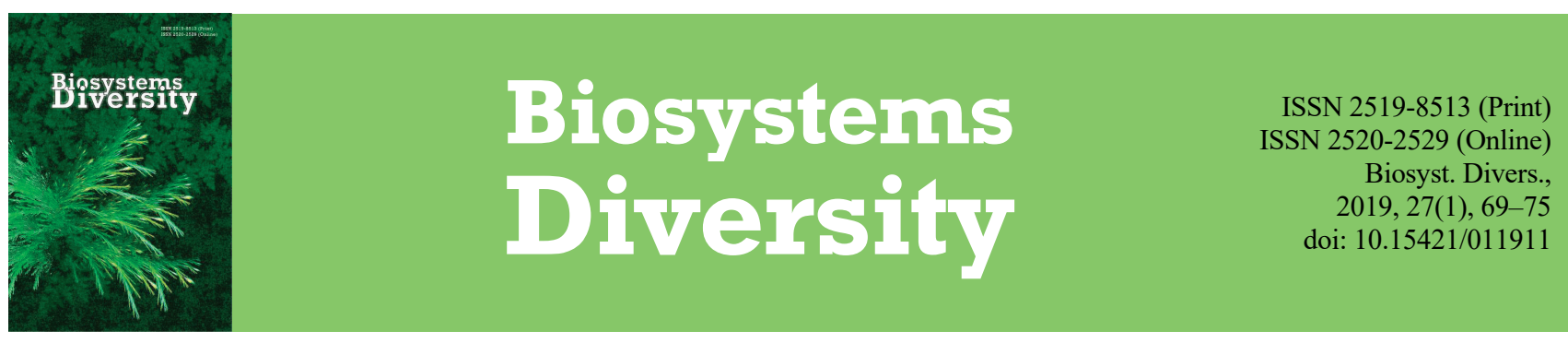

\title{
Investigation of vegetation as a precondition for improving the management of a national nature park (on the example of Dzharylhatskyi NP)
}

\author{
A. O. Davydova*, A. A. Ponomareva**, D. A. Davydov* \\ *M. G. Kholodny Institute of Botany, National Academy of Sciences of Ukraine, Kyiv, Ukraine \\ **National Nature Park "Nizhnedneprovsky", Kherson, Ukraine
}

Article info

Received 20.12.2018

Received in revised form 27.01.2019

Accepted 01.02.2019

M. G. Kholodny Institute of Botany, NAS of Ukraine Tereshchenkivska st., 2, Kyiv, 01004, Ukraine.

Tel.: +38-099-079-01-08

E-mail:

anasta3Kz@gmail.com

\begin{abstract}
Davydova, A. O., Ponomareva, A. A., \& Davydov, D. A. (2019). Investigation of vegetation as a precondition for improving the management of a national nature park (on the example of Dzharylhatskyi NP). Biosystems Diversity, 27(1), 69-75. doi:10.15421/011911
\end{abstract}

The protected area of Dzharylhatskyi National Park is only $3 \%$ of the total area. This is not enough to preserve dynamic ecosystems that are very vulnerable to natural factors and almost impossible to restore following damage by anthropogenic factors. In the investigated area there are territories with high potential for conservation, which are characterized by the presence of species from the Red Data Book of Ukraine and International Red Lists, plant communities from the Green Data Book of Ukraine and biotopes of global significance. The proposed ten sites should receive protected status, which will bring the protected area up to the necessary minimum to preserve the rare ecosystems of the park from tourism and economic pressure, which have intensified in recent years. For the period of research in 2014-2018, 14 types of sozophytes were identified and confirmed, two of them are the highly localised species endemic to Dzharylhach Island: Molinia euxina Pobed. and Poacynum russanovii (Pobed.) Mavrodiev, A. Laktionov et Y. Alexeev. The syntaxonomic structure of the sozologically valuable coenoses is represented by two basal communities, two subassociations and 8 associations belonging to 9 alliances, 9 orders and 9 classes. Out of them, we provisionally propose the new following groups: ass. Apero maritimi-Chrysopogonetum grylli nom. prov., subass. Apero maritimiChrysopogonetum grylli, Stipetum borysthenicae nom. prov., subass. Cladietum marisci, Caricetum extensae nom. prov., BC Molinia euxina [Molinion caeruleae] nom. prov. The proposed sites represent 8 biotopes from Annex I of the Habitat Directive, which imposes obligations for their conservation at the world level. We carried out an analysis of the Ukrainian legislative acts, their correlation with international requirements and the zoning of the NPP "Dzharylhatskyi" in relation to these requirements and recommendations. Thus, the urgent need to expand the boundaries of the protected area of the Dzharylhatskyi National Nature Park by including distinguished protected tracts has been confirmed.

Keywords: mapping; vegetation; sozophytes; biotope conservation; zoning optimization; national nature park "Dzharylhatskyi".

\section{Introduction}

The problem of management of recently created protected territories exists in many countries: the problems of reconciliation of previous scientific results and modern data; the issue of coordination of changes with land users in connection with the introduction of a nature reserve regime; legal conflicts related to the interpretation of legislative environmental documents (Naqinezhad, 2012; Wang et al., 2012; Kaneko \& Nohara, 2014; Malchykova et al., 2009). As a rule, forming a list of rare species and mapping their locations (or places for representatives of the fauna) is the basis of the scientific substantiation of creating of the Nature Reserve Fund. And, unfortunately, during the next stage - coordination with land users - the scientific value of the territory does not play such an important role. Problems arising when developing zoning or when there is conscious interference of interested land users in reducing the volume of territories are particularly acute if the protected object is also a touristic place, that is, it suffers from excessive recreational influence.

In the territory of national nature parks, in accordance with the Law of Ukraine "On the Nature Reserve Fund of Ukraine", the following zones are defined: the protected zone, the zone of regulated recreation; the zone of stationary recreation and the agricultural zone (Zakon Ukrainy ..., 1992; Ponomareva, 2015). Zonation of the territory of the NPP and activity on its territory is carried out in accordance with the Regulations on the National Nature Park and the project of organization of its territory (Proekt organizacii ..., 2016). The functional zoning is made for division of territory into separate plots by the combination of certain dominant features and for the purpose of agricultural use. The main purposes of functional zoning are the provision of the optimal regime of use of certain parts of the territory of the national nature park, preservation and restoration of valuable natural complexes, following the normative requirements and scientific recommendations (Proekt organizacii ..., 2016). The previous variants of the functional zoning of the Dzharylhatskyi NP have been developed in different years, for example in the one developed in 2000, some parts of the protected areas represented territories with ornithological value (Ardamatskaya et al., 2000). The 2016 project, which was approved and is now the official document for the park, proposes one integral protected area within the borders of the Dzharylhatskyi Botanical Reserve (Proekt organizacii ..., 2016). But these projects, which were thoroughly theoretically developed, faced problems of coordination with the main land user - the Skadovske DLMG State Enterprise, so the zoning that exists now does not correspond to the goals and objectives of the national nature park.

The objective of this study was to reveal the problems of managing protected objects, in particular, the ways to detect inconsistencies in functional zoning on the example of the territory of the Dzharylhatskyi $\mathrm{NP}$ and the justification of changes in the zoning using local mapping of rare vascular plant species and their communities.

\section{Materials and methods}

The study is based on the materials of the field work conducted in 2014-2018. A total of 107 relevés of 3 to $25 \mathrm{~m}^{2}$ plot size were sampled in the study area according to the Braun-Blanquet approach (BraunBlanquet, 1964; Westhoff \& van der Maarel, 1973) and were used to 
develop syntaxonomy. The ecological-floristic classification was carried out using the "deductive" method of Kopecký-Hejný (Kopečky \& Hejny, 1974). Vegetational classification was conducted by means of Modified Twinspan (Roleček et al., 2009) modified in Juice 7.0.102 software package (Tichý, 2002).

To identify diagnostic species, the phi fidelity index was used. Insignificant values of fidelity (less than 0.001 ) were removed on the basis of Fischer's exact test. The fidelity threshold for distinguishing diagnostic species is at least $25 \%$, for highly diagnostic species $-50 \%$. We used the modified scale of the projective cover of species by B. M. Mirkin in developing phytocoenotic tables, where we used: $+-<1 \%, 1-$ $1-5 \%, 2-6-15 \%, 3-16-25 \%, 4-26-50 \%, 5->50 \%$.

Syntaxa names were specified according to the International Code of Phytosociological Nomenclature (Weber et al., 2000). The higher syntaxonomic units are given according to the latest publications of Europe and Ukraine (Mucina et al., 2016; Solomaha et al., 2017). Plant species names are given in accordance with "Vascular Plants of Ukraine. A nomenclatural checklist" (Mosyakin \& Fedoronchuk, 1999). Some taxa, the names of which need clarification, are cited with reference to relevant sources.

Vegetation mapping has been carried out in accordance with syntaxa of Braun-Blanquet classification. All plant communities with their dynamic status were identified as concrete syntaxa, both indigenous and introduced. Phytosociological maps of actual (or "real") vegetation in this work show the spatial distribution of vegetation units belonging to associations and groups of associations, and the alliances within which they are represented. Plant associations are shown by different colours in accordance with the phytosociological system, all associations belonging to a particular alliance are represented by the same colour but with different tones (Pedrotti, 2013). Mapping results are presented in the geoinformation system QGIS 2.18.24 (Brown \& Weber, 2011).

\section{Results}

The Dzharylhatskyi National Nature Park is situated in Kherson Oblast of Ukraine. It consists of Dzharylhach Island and mainland areas along coast line. Located in the north-western part of the Black Sea, it is washed by the Dzharylhach Bay to the north. The area of the island is 5065 hectares. Its total length is about $42 \mathrm{~km}$, the width varies from $4.6 \mathrm{~km}$ to $100 \mathrm{~m}$ (Proekt organizacii' ..., 2016).

In terms of origin, Dzharylhach is an elevated sand/shell spit which was formed at the beginning of the Quaternary period due to the excavation of bed sediments. According to the model of reconstruction of the shape of accumulative forms and the northern coast in different periods of change in the level of the north-western part of the Black Sea, 700-1700 years ago the island was still the eastern part of the two-lobed shoal of Dzharylhach-Tendra (Pravotorov, 1967). The island in its present state can be divided into two different parts - the wide east part, $23.2 \mathrm{~km}$ long and the narrow western part, $18.5 \mathrm{~km}$ long. The relief on the wide part of the island is represented by dune formations and intermittent declivities. In the direction from the sea coast of the island to the bay, the altitude of the dunes decreases, weakly vegetated sand becomes replaced by level steppe areas, and dry depressions - by wet saline meadows and salt marshes (Ardamatskaya et al., 2000).

The main features of climate are the predominance of eastern and north-eastern winds, relatively low humidity, low cloud cover, low rainfall and relatively high daily and annual amplitudes of air temperature fluctuations (Proekt organizacii' ..., 2016).

The peculiarities of the island's microrelief and the depth of groundwater led to the differentiation of soils. They are represented by meadow-swamp, marsh, salt marshes, soil with fragments of shells, sandy grassy and sandy loam soil types and a large number of their subtypes (Ardamatskaya et al., 2000). There is one type of vegetation in the studied area according to the Map of the Natural Vegetation of Europe - western and central Pontic desert steppes (Bohn et al., 2004).

Since the development of the project of organization of the Dzharylhatskyi NNP (Proekt organizacii' ..., 2016), 805 hectares are in permanent use of the park; these lands are included in the total area of the park, which is 10,000 ha. 6,726 hectares belong to the forestry, and 2,469 hectares of the Dzharylhach Bay of the Black Sea are part of the park without being taken from the land users. The total area of the reserve zone is 300 hectares, it is represented by the Dzharylhatskyi National Botanical Reserve created in 1974 (Fig. 1).

In total in 2014-2018, 14 rare plant species (sozophytes) were found on the territory of the Dzharylhatskyi NP, which differs from the results of the literature sources analysis (Boyko, 1988; Ardamatskaya et al., 2000; Shaposhnikova, 2015). Ten species are included in Red Data Book of Ukraine (Didukh, 2009). The list of species included in Red lists of different levels (not all those from the list of the Kherson region but only those that are local endemics or presented in other lists) is proposed below (Table 1). This list does not include species from the European Red List of Vascular Plants that are common to this region and Ukraine as a whole (Cichorium intybus L., Lactuca tatarica (L.) C. A. Mey., Lemna minor L., Lepidium ruderale L., Phragmites australis (Cav.) Trin. ex Steud. etc.).

All species localities are confirmed by GPS coordinates, the data has been used for developing the map. As a result of mapping of the sozophytes in the Dzharylhatskyi NP, 14 rare species were found in 57 localities. Separately, the mapping of Chrysopogon gryllus was carried out at the level of plant groups, due to its domination in separate parts of the island. Therefore, the extreme points of this species are given, and the ecological-floristic classification is enclosed with all locations of record - 156 individual polygons on the map, separated by dozens and hundreds of meters (Fig. 2). The phytosociological maps of the actual vegetation represent the vegetation that was observed during the survey. We distinguished associations within the alliances. In some cases, alliances were separated by biotopic affiliation. For sozophytes, we provide their belonging to certain alliances and biotopes (except for Anacamptis picta and Stipa capillata, the locations of which are distorted by anthropic influence, therefore, it is possible to distinguish only groups, and not syntaxonomic units).

It should be mentioned that there are two highly localised endemic species for which the Dzharylhach Island is the locus classicus: Molinia euxina Pobed. and Poacynum russanovii (Pobed.) Mavrodiev, A. Laktionov \& Y. Alexeev; they form associations (Fig. 3, 4).

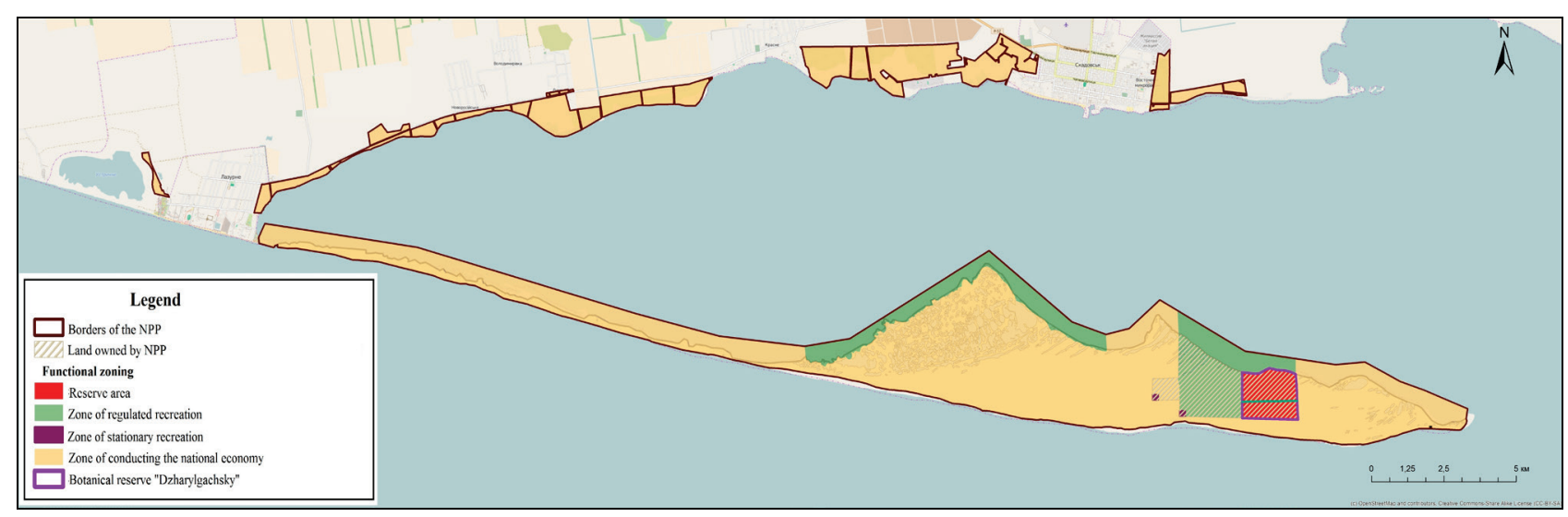

Fig. 1. Functional zoning of the NPP "Dzharylhatskyi" (based on materials of the project of organization with additions by authors) 
Table 1

Vascular plant species from the world, national and regional red lists (sozophytes) confirmed on the territory of NPP "Dzharylhatskyi" in 2014-2018 and their conservation status

\begin{tabular}{|c|c|c|c|c|c|c|c|}
\hline The Latin name & RBU & $\mathrm{RLCH}$ & IUCN & ERL (A.II) & CITES (A.II) & BernC (A.I) & BuchC \\
\hline Anacamptis coriophora (L.) R. M. Bateman, Pridgeon \& M. W. Chase & $+\mathrm{V}$ & - & - & $+\mathrm{LC}$ & + & - & - \\
\hline Anacamptis laxiflora subsp. palustris (Jacq.) Kuropatkin \& Efimov *1 & $+\mathrm{V}$ & - & $+\mathrm{LC} / \mathrm{D}$ & - & + & - & - \\
\hline Anacamptis picta (Loisel.) R. M. Bateman & $+\mathrm{V}$ & - & - & - & + & - & - \\
\hline Chrysopogon gryllus (L.) Trin. & $+\mathrm{V}$ & - & - & - & - & - & - \\
\hline Cladium mariscus subsp. martii (Roem. \& Schult.) T. V. Egorova & $+\mathrm{V}$ & - & - & $+\mathrm{LC}$ & - & - & - \\
\hline Crambe maritima L. & $+\mathrm{V}$ & - & - & - & - & - & - \\
\hline Ephedra distachya $\mathrm{L}$. & & $+\mathrm{R}$ & $+\mathrm{LC} / \mathrm{S}$ & - & - & - & - \\
\hline Frankenia pulverulenta $\mathrm{L}$. & $+\mathrm{V}$ & - & - & - & - & - & - \\
\hline Molinia euxina Pobed. $*^{2}$ & - & $+\mathrm{R}$ & - & - & - & - & - \\
\hline Nanozostera noltii (Hornem.) Toml. \& Posl. $*^{3}$ & - & - & $+\mathrm{LC} / \mathrm{D}$ & - & - & - & $+\mathrm{R}$ \\
\hline Poacynum russanovii (Pobed.) Mavrodiev, A. Laktionov \& Y. Alexeev *4 & $+\mathrm{V}$ & - & - & - & - & - & - \\
\hline Stipa borysthenica Klokov ex Prokudin & $+\mathrm{V}$ & - & - & - & - & - & - \\
\hline Stipa capillata $\mathrm{L}$ & $+\mathrm{U}$ & - & - & - & - & - & - \\
\hline Zostera marina L. & - & - & $+\mathrm{LC} / \mathrm{D}$ & - & - & + & $+\mathrm{R}$ \\
\hline
\end{tabular}

Notes: RBU (Red Data Book of Ukraine): V - vulnerable, U - unvalued; RLKHR (Red List of Kherson Region): R - rare; IUCN (International Union for Conservation of Nature's Red List of Threatened Species): LC - Least Concern, population trend: D - decreasing, S - stable; ERL (European Red List of Vascular Plants): LC - Least Concern; CITES (Convention on International Trade in Endangered Species of Wild Fauna and Flora): A.II - appendix II; BernC (Bern Convention, Convention on the Conservation of European Wildlife and Natural Habitats): A.I - appendix I; BuchC (Bucharest Convention, Convention on the Protection of the Black Sea against Pollution): R - rare; - not indicated; * - some taxa, whose names need to be clarified, are cited with reference to relevant sources: 1 - Kuropatkin \& Efimov (2014); 2 - Pobedimova (1949); 3 - Tomlinson \& Posluszny (2001); Bartoluccia et al. (2018); 4 - Mavrodiev et al. (2015).

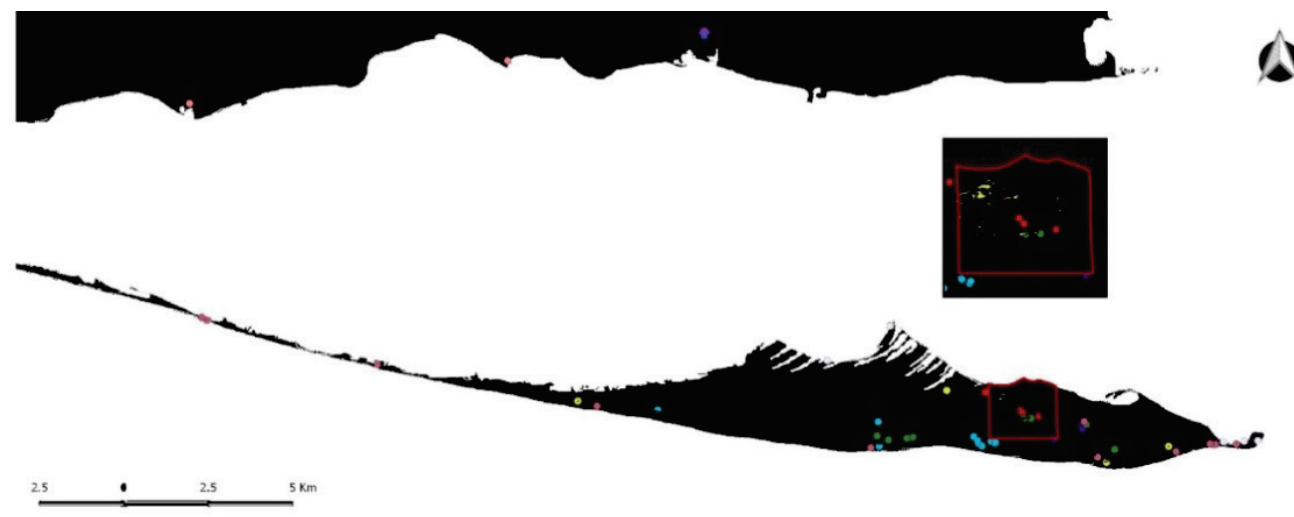

Legend

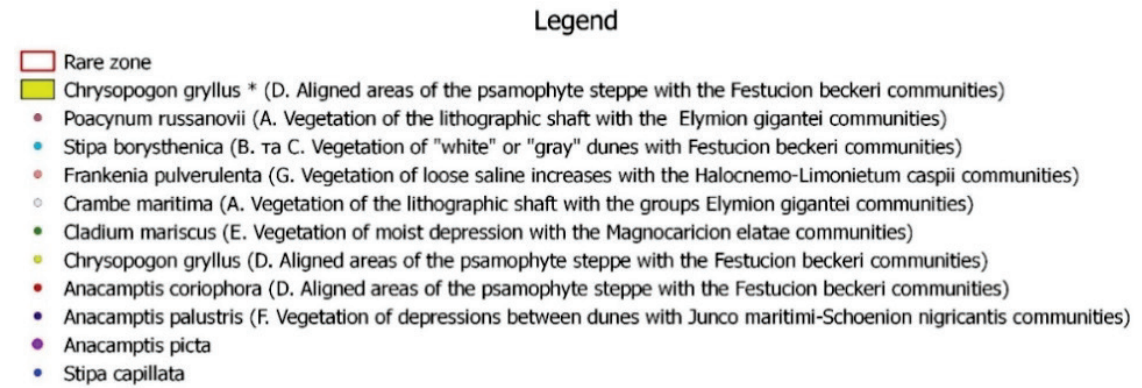

Fig. 2. Map of distribution for species from the Red Data Book of Ukraine and rare plant communities in the territory of the Dzharylhatskyi NP

The fact that the species of the genus Molinia Schrank really grows in the southernmost isolated locality of Ukraine and forms a community is not in doubt, but there are different views on Molinia euxina Pobed. as a separate species. It was described from Dzharylhach Island in 1949 (Pobedimova, 1949a). In later works it was synonymized with Molinia caerulea $(\mathrm{L}$.) Moench, in particular in one of the recent works about the cytogeography of the Molinia genus in Central Europe (Dančák et al., 2012). However, despite a large number of investigated samples, $M$. euxina is considered as a synonym based on only morphological parameters (over the study of a typical herbarium specimen of this species). Therefore, taking into account a number of morphological features cited in the protologue which indicate differences between M. euxina and M. caerulea, the absence of objective reasons (conclusions of molecular phylogenetic studies) for making them synonymous and geographic isolation, we consider it correct to consider M. euxina a separate species (Fig. 3).

The second endemic species - Poacynum russanovii - was for the first described as Apocynum russanovii Pobed. in 1949 (Pobedimova, 1949b). In the "Flora of the USSR" it was indicated as Trachomitum russanovii (Pobed.) Pobed. with two forms - f. latifolium Illicz. and f. angustifolium Illicz. (Pobedimova, 1952). In 2007 this taxon was cited in the rank of subspecies - Trachomitum venetum subsp. russanovii (Pobed.) Yena et Moysienko (Yena \& Moysienko, 2017), and subsequently, in view of the recircumscription of the genus Poacynum Baill., a new combination of Poacynum russanovii (Pobed.) Mavrodiev, A. Laktionov \& Y. Alexeev (Mavrodiev et al., 2015) was proposed. Based on the lack of detailed study of the taxonomic complex Poacynum venetum (L.) Mavrodiev, A. Laktionov \& Y. Alexeev s.l. we still accept the name in the ranks of the species - Poacynum russanovii.

In 2007, it was distinguished as a subspecies Trachomitum venetum Woodson subsp. russanovii (Pobed.) Yena et Moysienko. However, a 2015 study focused on taxonomic changes related to determining the Poacynum Baill, genus, allows us to distinguish new combination Poacynum russanovii (Pobed.) Mavrodiev, A. Laktionov et Y. Alexeev.

The study of the vegetation of Dzharylhach Island began in the early XX century (Shaposhnikova, 2017a). Systematic geobotanical research in the territory of the Dzharylhatskyi NP by one of the authors 
(A. O. Davydova) has been carried out since 2016. From the general classification scheme of the NP Dzharylhatskyi vegetation, we have distinguished syntaxa which contain rare species as diagnostic, dominant or constant plants. The syntaxonomic structure of these sozologically valuable coenoses is represented by 2 basal communities, 2 subassociations and 8 associations from 9 alliances, 9 orders and 9 classes.
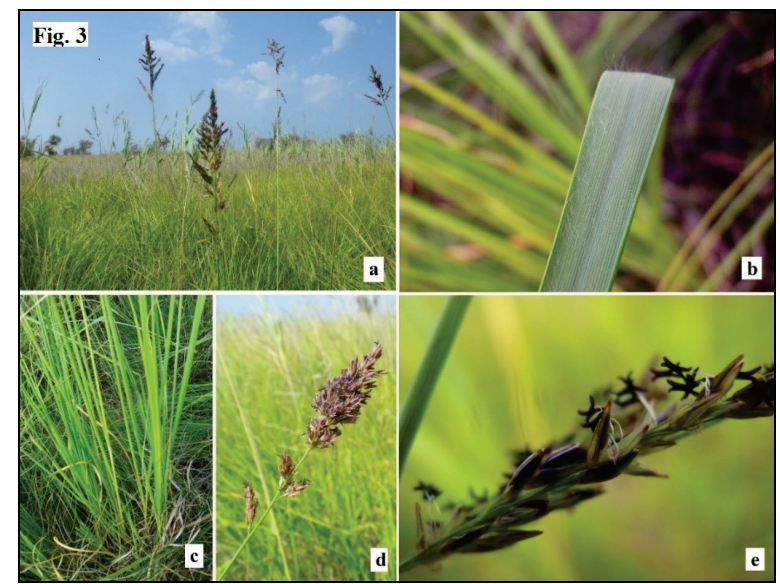

Fig. 3. General view and parts of the plant: $a$ - growth of Molinia euxina; $b$-narrow rigid leaves; $c$ - sparse tussock; $d$-short and dense panicle; $e-2$-flowered spikelets with narrow and short scales (Dzharylhach Island, 26 August 2018, photo by A. Davydova)

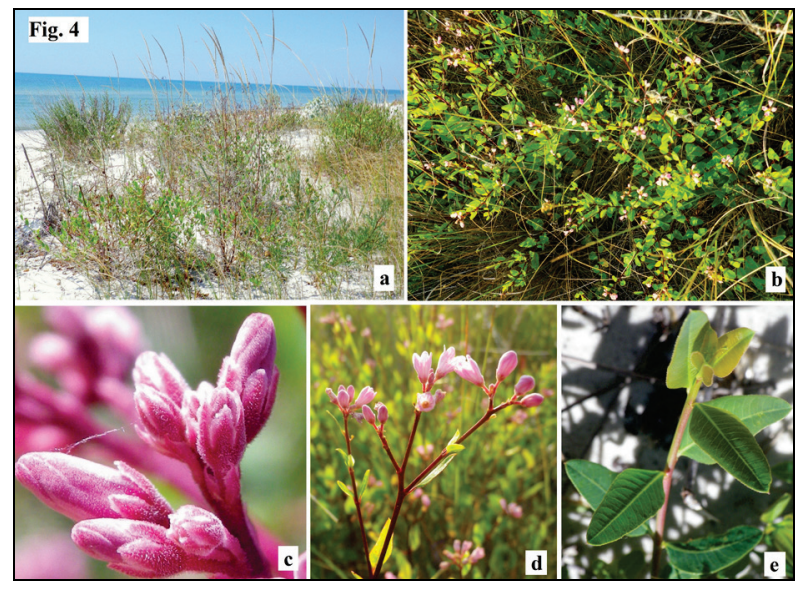

Fig. 4. General view and parts of the plant: $a$ - growth of Poacynum russanovii on dunes; $b$-growth of $P$. russanovii in wet depression between dunes; $c$ - pubescent peduncle and calyx; $d$-few-flowered inflorescence plate and the bark of the stem which are bright red; $e-$

oblong petiolate leaves (Dzharylhach Island, $c, e-7$ June 2015,

$$
a, b, d-9 \text { August 2017, photo by A. Davydova) }
$$

We first established several new syntaxa described during the geobotanical analysis of psamophytic, coastal and meadow vegetation. Further, we consider some syntaxa, in whose formation rare species form a major part. BC Poacynum russanovii [Elymion gigantei] is a basal community, the dominant species of which is $P$. russanovii (Pobed.) Mavrodiev, A. Laktionov \& Y. Alexeev - a highly localised endemic coastal species. This community was proposed by us in 2017 after data analysis within the Ammophiletea class of Dzharylhach Island (Shaposhnikova, 2017b). It occupies small areas of the littoral zone. The total projective cover of the herb layer in these communities is $50 \%$, the dominant P. russanovii occupies $35-40 \%$. Less abundant plants (up to $10 \%$ cover) are Carex colchica J. Gay, Centaurea odessana Prodan, Cynanchum acutum L., Eryngium maritimum L., Picris hieracioides L., and others occur.

The association Apero maritimi-Chrysopogonetum grylli, the dominant species of which is Chrysopogon gryllus, we tentatively suggest as new to science. According to the floristic composition, it is close to the association of Dauco guttati-Chrysopogonetum grylli Popescu, Sanda \& Doltu 1980, described from Romania, but it differs by the absence (generally in the flora of Ukraine) of Daucus guttatus Sibth. \& Sm, after which the association is named and which is diagnostic for the syntaxon, and the presence of Apera maritima Klokov, Milium vernale M. Bieb., Rumex acetosella L., Secale sylvestre Host etc. The local area of this syntaxon, on the one hand, provides grounds for considering it as a separate unit, but on the other hand, the absence of similar communities in Ukraine prevents comparisons with floristic composition and leading environmental factors (Sanda et al., 2008). For this syntaxon, two subassociations are proposed: Apero maritimi-Chrysopogonetum grylli typicum and Apero maritimi-Chrysopogonetum grylli Stipetosum borysthenicae. The latter differs from the typical by the presence of xerophytic species Stipa borysthenica Klokov ex Prokudin, Euphorbia seguierana Neck., Koeleria sabuletorum (Domin) Klokov. Floral saturation of the communities - 12-17 species in Apero maritimi-Chrysopogonetum grylli typicum and 8-15 species in Apero maritimi-Chrysopogonetum grylli Stipetosum borysthenicae.

Phytocoenoses with the domination of Cladium mariscus subsp. martii are very valuable on the territory of the Dzharylhatskyi NP. They are provisionally distinguished as a new subassociation Cladietum marisci Caricetosum extensae Davydova prov. Diagnostic species of subassociation are Phragmites australis (Cav.) Trin. ex Steud., Lythrum salicaria L., Mentha aquatica L., Carex extensa Gooden. The confirmation of this new syntaxon requires the analysis of all PhragmitoMagnocaricetea specimens collected from Dzharylhach Island and a comparison with geobotanical relevés and floristic composition within the entire range of Cladium mariscus. In the territory of NPP, these communities are widespread in the wet depression of the central part of the Dzharylhach Island. Projective herb layer cover - 90\%, dominant (Cladium mariscus subsp martii) occupies 50-65\%, co-dominant (Phragmites australis) - 35-45\%. The accompanying species are Lycopus europaeus L., Mentha aquatica L. Floristic saturation - 7-9 species.

Another syntaxon within the Dzharylhatskyi NP, which raises controversial issues related to its recognition as a separate species and differences in the floristic composition to similar northern phytocoenoses, is the Molinia euxina basal community from the alliance Molinion caeruleae Koch 1926. These coenoses now occupy very limited areas in the central part of the island in the depressions of the ecotone strip between the psamophytic, coastal and halophytic communities. The total cover of the herb layer is $70-80 \%$, the share of M. euxina is $40-50 \%$. Floristic saturation is 7-12 species, the accompanying species are Galium verum L., Pulicaria dysenterica (L.) Gaertn., Phragmites australis (Cav.) Trin. ex Steud., Schoenus nigricans L.

Since other rare species are represented in plant communities individually or represent a small proportion of the vegetation of a certain community, we restrict ourselves to the classification scheme of the syntaxa in which they are presented in the characterization of protected tracts below. Since the study of higher aquatic vegetation outside the Dzharylhach Island is not our task, we give the names of syntaxa which include Zostera marina L. and Nanozostera noltii (Hornem.) Toml. \& Posl. This is the association Zosteretum marinae Harmsen 1936 and Zosteretum noltii Harmsen 1936 (alliance Zosterion marinae Br.-Bl. et Tx ex Pignatti 1953, order Zosteretalia Béguinot ex Pignatti 1953, class Zosteretea Pignatti 1953) respectively.

\section{Discussion}

Thus, on the territory of the NPP "Dzharylhatskyi" we were the first to carry out the mapping of the sozophytes based on the field data only, without drawing the unconfirmed points of early indicated species. These very data are valuable for the writing of the Chronicle of Nature of the NPP and the study of population characteristics.

The main function of the protected area of the park is the preservation of the Mediterranean species Chrysopogon gryllus (L.) Trin at the northern border of its range. Due to the specifics of the management of the land user (forestry), the reserve was designated within four quarters. But since the reserve was created, this species has considerably expanded its population area beyond the boundaries of the preserve in the southwestern direction. The vegetation of the interior flat interfluves and flattened dunes is unique due to the large area of the growth of Chryso- 
pogon gryllus in combination with Stipa borysthenica. In addition to the above-listed protected species, Anacamptis coriophora grows within the protected area. In the central part, the reserve is crossed by a road that is actively used during the tourist season and also for the agricultural needs of the forestry. The vast majority of Anacamptis laxiflora subsp. palustris plants grows in the agricultural zone. It should be noted that the localities are in the close proximity of the road, forestry facilities and lakes, to which animals come to drink. In these meadow communities, individual plants of Poacynum russanovii grow. Localities in the eastern part of the island tend to the coastal elevation with flooded hollows behind the littoral embankment. Individual species are also found within the psamophytic-steppe part. The depression in the central part of the island is an area of distribution of Cladium mariscus subsp. martii, a relict subspecies. The vegetation of the littoral embankment areas, in particular the numerous populations of Crambe maritima, remains outside the protected territories. All these growing locations with rare species are located within the economic zone and the zone of regulated recreation.

For the first time in the long history of Dzharylhach Island, areas along the coast of the Dzharylhach Bay became a part of the national nature park (exclusively within the economic zone). Almost half of the land is covered by forest plantations, a quarter is under arable land and pastures (Project, 2016). Only a small percentage of the salt marshes, which are becoming degraded due to cattle grazing and, in some cases steppe vegetation, has been preserved.

Why did the idea of optimizing the Dzharylhatskyi NP occur? Functional zoning of national nature parks involves the following division: a protected zone, a zone of regulated recreation and stationary recreation, an agricultural zone (Zakon Ukrainy ..., 1992). According to the project of the Dzharylhatskyi NP, the reserve area is $3.0 \%$ of the total area, the zone of regulated recreation is $13.4 \%$, the zone of stationary recreation is $0.08 \%$, the agricultural zone is $83.5 \%$ (Proekt organizacii ..., 2016). According to the methodological recommendations of the "Chronicle of Nature Programs for Nature Reserves and National Parks" the size of the areas of the protected area is determined by international standards that are characteristic of national parks (II category of IUCN). And do national natural parks, as a category of Nature Reserve Fund of Ukraine, meet these criteria? According to the "Guidelines for Applying Protected Area Management Categories", Category II aims to minimize human activity in order to allow "as natural a state as possible". Category V includes an option of continuous human interaction. Category II of protected areas are set aside to protect large-scale ecological processes along with the complement of species and ecosystems characteristic of the area, which also provide a foundation for environmentally and culturally compatible spiritual, scientific, educational, recreational and visitor opportunities (Guidelines ..., 2008). Consequently, national nature parks of Ukraine, if relying on the Law of Ukraine "On the Nature Reserve Fund of Ukraine" correspond more to category V than II. But, as stated in this guide: "The name "national park" is not exclusively linked to Category II. Places called national parks exist in all the categories (and there are even some national parks that are not protected areas at all). The fact that an area is called a national park is independent of its management approach" (Guidelines ..., 2008).
Since it is not expedient to use these definitions for the IUCN at the present time, let us turn to domestic legislation and methodological recommendations. So: "The priority and decisive value in the functional zoning is the protected area, which is allocated first of all. It ensures the performance of the NP of the first and main function" (Andrijenko et al., 2002). If we compare this statement and the size of the protected area of the Dzharylhatskyi NP (3.0\% of the total area), it becomes clear that the protected zone and its functions in this case are not a priority. And even if there are disputed questions such as what type of region and what extent of disturbance an object should be classified as, the percentage of the protected area should be at least $25 \%$ (and up to $75 \%$ ) (Andrijenko et al., 2002). The following statement indicates that "the protected area should include biodiversity with its red list (European Red List of Animals and Plants, Red List of the International Union for the Conservation of Nature and Natural Resources, Red Data Book of Ukraine), the Green Data Book of Ukraine, and also to conventions, international agreements" (Andrijenko et al., 2002). Indeed, as can be seen on the map (Fig. 2), some of the mentioned conditions coincide, but at the same time the map shows a range of unprotected localities of rare species of vascular plants, plant communities and biotopes.

Consequently, based on the data on the chorology of the consortia and syntaxa to which they belong, we can state that the protected zone within its current limits cannot fulfill the function of preserving the biodiversity (in particular, plant complexes) of the national park (Fig. 1-2). According to the analysis of the database of geobotany relevés for the territory of the park, vegetation mapping and localities of rare species, we propose to optimize the functional zoning of this object of the nature reserve fund. According to the methodological recommendations of the "Chronicle of Nature Programs for Reserves and National Parks": "in case of the impossibility of locating zones in concentric circles, other sozologically practical modifications of functional zoning are introduced - largescale, cluster, palliative zonings, etc. The protected zone may have sites of especially valuable natural complexes within other zones. In the case of distinguishing such complexes within the agricultural area or zone of stationary recreation, they are surrounded by areas of the regulated recreation zone" (Andrijenko et al., 2002). Unfortunately, because of the categorical attitude of the land user - Skadovsk DLMG the state enterprise, - this is impossible in the near future. Therefore, as an alternative, we propose the allocation of ten protected tracts - three on the mainland of the national nature park and seven on Dzharylhach Island (Fig. 5). According to the Law of Ukraine "On the Nature Reserve Fund of Ukraine", forest, steppe, marsh and other isolated integral landscapes which have an important scientific, environmental and aesthetic value are declared with protected tracts in order to preserve them in a natural state (Zakon Ukrai'ny ..., 1992). For the projected protected areas, there have been considered indicators such as the presence of species from the Red Data Book of Ukraine and communities from the Green Data Book of Ukraine (GDBU), the possibility of distinguishing biotopes included in the list of the Habitat Directive (Natura 2000), and close relation to ecological conditions and floristic composition (Didukh, 2009a, b; Natural ..., 2003). The most valuable areas are shown on the map with gradient green colour (size of the conditionally defined areas depends on the distances between the extreme points).
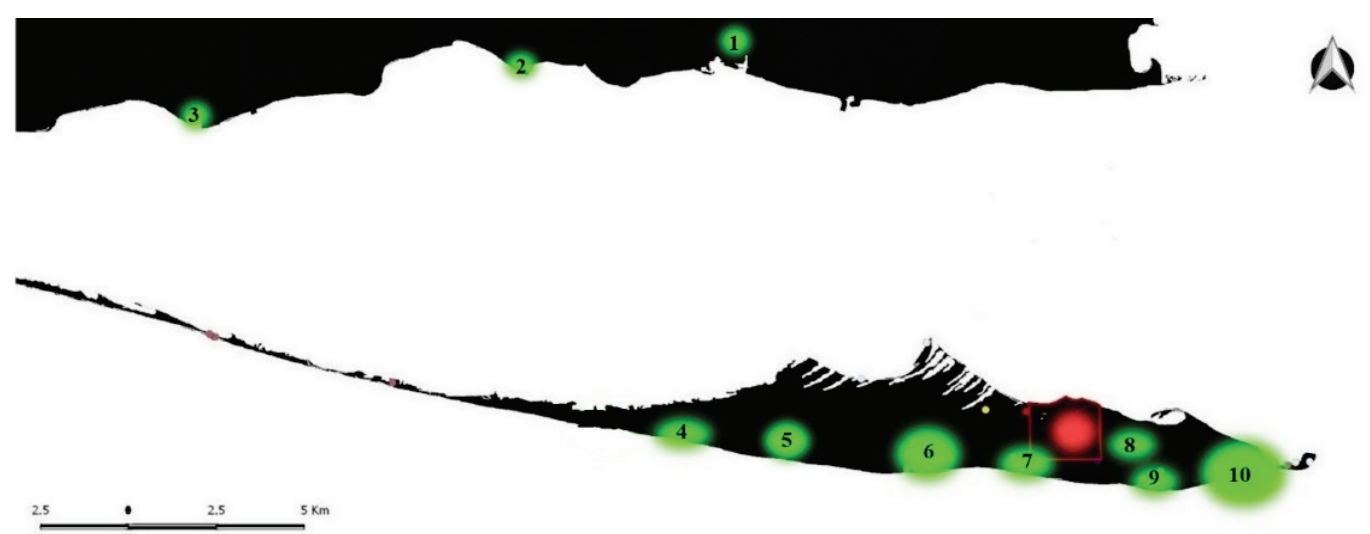

Fig. 5. Map of distribution of potential sites (tracts) for conservation: red - reserve area, green - potential sites for conservation 
Tract 1 is represented by transformed raised steppe areas with Stipa capillata among salt marshes and saline meadows with individual plants of Anacamptis picta. Natura 2000: 6210 Semi-natural dry grasslands and scrubland facies on calcareous substrates (Festuco-Brometalia) (important orchid sites). GDBU: communities of Stipeta capillatae (association Stipetum (capillatae) festucosum (valesiacae). The approximate area for reservation is 1.1 hectares.

Tracts 2 and 3 represent humid salt marshes with shrubs and ephemeral plants. In addition to typical biotopes, the objective of the preservation is two isolated populations of Frankenia pulverulenta. Natura 2000: Mediterranean and thermo-Atlantic halophilous scrub (Sarcocornetea fruticosi). The estimated area is 3.6 and 3.8 hectares respectively. According to the ecological-floristic classification we distinguished two associations: Petrosimonio oppositifoliae-Salicornietum Korzhenevsky \& Klyukin in Dubyna et al. 2007 (alliance Salicornion prostratae Gehu 1992, order Camphorosmo-Salicornietalia Borhidi 1996, class Therosalicornietea Tx. in Tx. \& Oberd. 1958) and Halocnemo-Limonietum caspii Korzhenevsky \& Klyukin in Korzhenevsky 2000 (alliance Artemisio santonicae-Puccinellion fominii Shelyag-Sosonko, Golub \& Solomakha 1989, order Halimionetalia verruciferae Golub et al. 2001, class Kalidietea foliati Mirkin et al. ex Ruhlenko 2012).

Tract 4 is the westernmost psamophytic-steppe community with Chrysopogon gryllus (some points are further west) and Stipa borysthenica. Natura 2000: 2130 Fixed coastal dunes with herbaceous vegetation ("grey dunes"). GDBU: communities of Chrysopogoneta gryllis (associations of Chrysopogonetum (gryllis)-Scirpoidosum (holoschoeni), $C$. aperosum (maritimae), communities of Stipeta borysthenicae (association Stipetum (borysthenicae) Festucoso (beckeri)-Koeleriosum (sabuletorii). According to the ecological-floristic classification, we distinguished the association Apero maritimi-Chrysopogonetum grylli Davydova nom. prov. and the subassociation Apero maritimi-Chrysopogonetum grylli-Stipetosum borysthenicae Davydova nom. prov. (alliance Festucion beckeri Vičherek 1972, order Festucetalia vaginatae Soó 1957, class Festucetea vaginatae Soó ex Vičherek 1972).

Tract 5 is one of the largest tracts of Chrysopogon gryllus outside the protected area. Natura 2000: 6260 Pannonic sand steppes. GDBU: communities of Chrysopogoneta gryllis (associations Chrysopogonetum (gryllis)-Scirpoidosum (holoschoeni), C. calamagrostidosum (epigeioris) and $C$. aperosum (maritimae). The area of tract is 3.2 hectares. According to the ecological-floristic classification we distinguished here the association Apero maritimi-Chrysopogonetum grylli Davydova nom. prov. (alliance Festucion beckeri, order Festucetalia vaginatae, class Festucetea vaginatae).

Tract 6 is proposed for conservation of Cladium mariscus subsp. martii (the largest number of localities per unit area), Stipa borysthenica, Poacynum russanovii and two localities of Molinia euxina. Natura 2000: 7210 Calcareous fens with Cladium mariscus and species of the Caricion davallianae; 2130 Fixed coastal dunes with herbaceous vegetation ("grey dunes"). GDBU: communities of Cladieta marisci (association Cladietum (marisci)-Phragmitosum (australis). Approximate area is 3.4 hectares. According to the ecological-floristic classification we proposed new subassociation Cladietum marisci- Caricetosum extensae Davydova nom. prov. (association Cladietum marisci Allorge 1921, alliance Magnocaricion elatae Koch 1926, order Magnocaricetalia Pignatti 1953, class Phragmito-Magnocaricetea Klika in Klika et Novak 1941) and the basal community Molinia euxina (alliance Molinion caeruleae Koch 1926, order Molinietalia caeruleae Koch 1926, class MolinioArrhenatheretea Tx. 1937).

Tract 7 represents many Stipa borysthenica communities. Natura 2000: 2130 Fixed coastal dunes with herbaceous vegetation ("grey dunes"). The area of this site is 1 hectare. GDBU: communities of Stipeta borysthenicae (association Stipetum (borysthenicae) Festucoso (beckeri)koeleriosum (sabuletorii).

Tract 8 is proposed for the preservation of meadow communities with Anacamptis laxiflora subsp. palustris, Poacynum russanovii and humid depressions with Cladium mariscus subsp. martii. Natura 2000: 2190 Humid dune slacks; 7210 Calcareous fens with Cladium mariscus and species of the Caricion davallianae. GDBU: communities of $\mathrm{Cla}$ dieta marisci (association Cladietum (marisci) Phragmitosum (austra- lis). The approximate reserve area is 0.8 hectares would consist of three separate sections around the forestry buildings. According to the ecological-floristic classification, we established a new subassociation Cladietum marisci, Caricetosum extensae Davydova nom. prov. (association Cladietum marisci, alliance Magnocaricion elatae, order Magnocaricetalia, class Phragmito-Magnocaricetea) and association Carici distantis-Schoenetum nigricantis Géhu et al. 1986 (alliance Juncion maritimi Br.-Bl. ex Horvatić 1934, order Juncetalia maritimi Br.-Bl. ex Horvatić 1934, class Juncetea maritimi Br.-Bl. in Br.-Bl. et al. 1952).

Tract 9 is proposed for the protection the easternmost tracts with Chrysopogon gryllus, localities of Poacynum russanovii and the largest area of the Cladium mariscus subsp. martii community. Natura 2000: 6260 Pannonic sand steppes; 2190 Humid dune slacks; 7210 Calcareous fens with Cladium mariscus and species of the Caricion davallianae. GDBU: communities of the association Chrysopogonetum (gryllis) aperosum (maritimae) and communities of Cladieta marisci (association Cladietum (marisci)-Phragmitosum (australis). The approximate area is 15 hectares. According to the ecological-floristic classification we distinguished here the new subassociation Cladietum marisci- Caricetosum extensae Davydova nom. prov. (association Cladietum marisci, alliance Magnocaricion elatae, order Magnocaricetalia, class Phragmito-Magnocaricetea) and the new association Apero maritimi-Chrysopogonetum grylli Davydova nom. prov. (alliance Festucion beckeri, order Festucetalia vaginatae, class Festucetea vaginatae).

Tract 10 includes the communities of the littoral embankment represented by separate locations of Poacynum russanovii and Crambe maritimà. Natura 2000: 1210 Annual vegetation of drift lines; 2120 Shifting dunes along the coast with Ammophila arenaria ("white dunes"). The approximate area is 3 hectares. According to the ecologicalfloristic classification we determined the basal community of Poacynum russanovii (alliance Elymion gigantei Morariu 1957, order Ammophiletalia Br.-Bl. \& Tx. ex Westhoff et al. 1946, class Ammophiletea Br.-Bl. \& Tx. ex Westhoff et al. 1946) and the association Ephedro-Caricetum colchicae (Prodan 1939) Sanda \& Popescu 1973 (alliance Scabiosion ucranicae Sanda et al. 1980, order Medicago-Seselietalia tenderiensis Umanets \& I. Solomakha 1999, class Helichryso-Crucianelletea maritimae Gehu et al. in Sissingh 1974).

Thus, the total area of the projected sites for the reserve is 36.1 hectares. It is almost 9 times smaller than the total area of the current protected area. But the importance of these protected tracts is hard to evaluate as long as there is no opportunity to expand the protected area or change the status of the national nature park into a nature reserve. Is there an urgent need? Certainly, since the statement "in the territory of the zone of regulated recreation, stationary recreation and agricultural zone, any activity that leads or may lead to deterioration of the environment and and reduction of the recreational value of the park's territory is prohibited" (Proekt organizacii' ..., 2016) does not correspond to the reality due to the lack of the opportunity to regularly visit all remote areas of the protected object and small number of staff in the park administration.

\section{Conclusion}

The increasing interest among tourists leads to uncontrolled visits to Dzharylhach Island (without the possibility of restricting the activity of tourists beyond the recreational zones). Theoretically, the recreational zones along Dzharylhach Island's coast should not be accessible to them. But in practice, on the example of coastal vegetation, it is possible to observe depletion of the species composition and the weakening of the coenotic relations of the groups of the beach strip of the island (the zone of regulated recreation) due to the active development of temporary buildings and a large number of visitors. The central parts of the island (including the protected area) are crossed by roads with heavy transport and quadracycles. In the mainland area of the park, which is represented purely by the agricultural zone due to economic activity (intensive cattle grazing), the salt marshes and pontic grass steppes are being degraded. The discrepancy between the legal obligations and the actual functioning of the Nature Reserve Fund object is caused by the conflict of interests of the main land user, the tenants and the NPP. Taking into account the constant position of the land user in transferring to the NP 
other lands of the island in permanent use, we propose as priority measures the allocation of 10 protected tracts, the floristic and coenotic diversity of which fully meets the requirements of the Law of Ukraine "On the Nature Reserve Fund of Ukraine". In the long run, when protected status is given to the sites that represent not only rarity and phytogenetic diversity, most of the island should belong to the protected area.

\section{References}

Andrijenko, T. L., Popovych, S. J., Parchuk, G. V., Prjadko, O. I., Korotchenko, I. A., Gavrylenko, V. S., \& Dumenko, V. P. (2002). Programa litopysu pryrody dlja zapovidnykiv ta nacional'nyh pryrodnyh parkiv [The chronicle of nature program for nature reserves and national parks]. Akademperiodyka, Kyiv (in Ukrainian).

Ardamatskaya, T. B., Bilinskaya, O. S., Boyko, M. F., Geluta, V.P., Davydok, V. P., Dubyna, D. V., Zykov, A. E., Kondratenko, N. G., Kotenko, A. G., Kotenko, T. I., Movchan, J. V., Moysienko, I. I., Monchenko, V. I., Seljunina, Z. V., Starenkij, O. F., Tihonenko, J. J., Khodosovtsev, A. E., Chernjakov, D. A., Shejgas, I. J., \& Sheljag-Sosonko, J. R. (2000). Bioraznoobrazie Dzharylgacha: Sovremennoe sostojanie i puti sohranenija [Biodiversity of the Jarylgach: Modern state and ways for conservation]. Vestnik Zoologii, Kiev (in Russian).

Bartoluccia, F., Peruzzib, L., Galassoc, G., Albanod, Alessandrinie, A., Ardenghif, N. M. G., Astutib, G., Bacchettag, G., Ballellih, S., Banfic, E., Barberisi, G., Bernardoj, L., Bouvetk, D., Boviol, M., Cecchim, L., Pietron, R. D., Dominao, G., Fascettip, S., Fenug, G., Festiq, F., Foggir, B., Gallos, L., Gottschlicht, G., Gubelliniu, L., Iamonicon, D., Iberitev, M., Jiménez-Mejíasw, P., Lattanziv, E., Marchettix, D., Martinettoy, E., Masinz, R. R., Medaglid, P., Passalacquaaa, N. G., Pecceninii, S., Pennesiab, R., Pierinib, B., Poldiniab, L., Prosserq, F., Raimondoac, F. M., Roma-Marziob, F., Rosatip, L., Santangeload, A., Scoppolaae A., Scortegagnaaf, S., Selvaggiag, A., Selviah, F., Soldanoai, A., Stincaaj, A., Wagensommerak, R. P., Wilhalmal, T., \& Contia, T. (2018). An updated checklist of the vascular flora native to Italy. Plant Biosystems, 2, 179-303.

Bohn, U., Neuhäusl, R., Gollub, G., Hettwer, C., Neuhäuslová, Z., Raus, T., Schlüter, H., \& Weber, H. (2004). Map of the natural vegetation of Europe scale, 1:2500000. Landwirtschaftsverlag, Münster.

Boyko, M. F. (1988). Novi znahidky ridkisnyh ta znykajuchyh vydiv roslyn u Hersons'kij ta Mykolai'vs'kyj oblastjah [New discoveries of rare and endangered plant species in the Kherson and Mykolaiv regions]. Ukrainian Botanical Journal, 45(5), $84-87$ (in Ukrainian).

Braun-Blanquet, J. (1964). Pflanzensoziologie. Grundzuge der Vegetationskunde. Springer-Verlag, Wien.

Brown, G., \& Weber, D. (2011). Public participation GIS: A new method for national park planning. Landscape and Urban Planning, 102, 1-15.

Dančák, M., Duchoslav, M., \& Trávníček, B. (2012). Taxonomy and cytogeography of the Molinia caerulea complex in Central Europe. Preslia, 84, 351-374.

Didukh, Y. P. (Ed.). (2009). Chervona knyga Ukrainy. Roslynnyi svit [Red data book of Ukraine. Plant world]. Globalkonsaltyng, Kyiv (in Ukrainian).

Didukh, Y. P. (Ed.). (2009). Zelena knyga Ukrainy [Green data book of Ukraine]. Alterpres, Kyiv (in Ukrainian).

Dudley, N. (Ed.). (2008). Guidelines for applying protected area management categories. IUCN, Gland, Switzerland.

Kaneko, K., \& Nohara, S. (2014). Review of effective vegetation mapping using the UAV (unmanned aerial vehicle) method. Journal of Geographic Information System, 6, 733-742.

Kopečky, K., \& Hejny, S. (1974). A new approach to the classification of antropogenic plant communities. Vegetatio, 29(1), 17-20.

Kuropatkin, V. V., \& Efimov, P. G. (2014). Konspekt rodov Anacamptis, Neotinea i Orchis s. str. (Orchidaceae) flory Rossii i sopredel'nyh stran s obzorom problemy podrazdelenija Orchis s. 1. na otdel'nye rody [A review of the genera Anacamptis, Neotinea and Orchis s. str. (Orchidaceae) in the flora of Russia and adjacent countries, with considerations about subdivision of Orchis s. 1.]. Botanicheskij Zhurnal, 99(5), 555-593 (in Russian).

Malchykova, D., Bilyk, J., \& Ponomareva, A. (2009). Zapovidannja pryrodnyh terytorij $\mathrm{v}$ strukturi zahodiv z optymizacii' navkolyshn'ogo seredovyshha Hersonshhyny [Conservation of natural territories in the structure of measures with optimization of the environment of Kherson region]. Ekologichnyj Bjuleten, 2, 73-76 (in Ukrainian).

Mavrodiev, E. V., Laktionov, A. P., \& Alekseev, J. E. (2015). O novyh kendyrjah jugo-vostoka Evropejskoj Rossii v svjazi s priznaniem samostojatel'nosti roda Poacynum Baill. (Apocynaceae) [On new dogbanes of south-eastern
European Russia due to the acceptance of the genus Poacynum Baill. (Apocynaceae)]. Novosti Sistematiki Vysshih Rastenij, 46, 157-163 (in Russian).

Mosyakin, S. L., \& Fedoronchuk, M. M. (1999). Vascular plants of Ukraine. A nomenclature checklist. M. G. Kholodny Institute of Botany, Kyiv.

Mucina, L., Bültmann, H., Dierßen, K., Theurillat, J.-P., Raus, T., Črni, A., Šumberová, K., Willner, W., Dengler, J., García, R. G., Chytrý, M., Hájek, M., Di Pietro, R., Iakushenko, D., Pallas, J., Daniëls, F. J. A., Bergmeier, E., Guerra, A. S., Ermakov, N., Valachovič, M., Schaminée, J. H. J., Lysenko, T., Didukh, Y. P., Pignatti, S., Rodwell, J. S., Capelo, J., Weber, H. E., Solomeshch, A., Dimopoulos, P., Aguiar, C., Hennekens, S. M., \& Tichý, L. (2016). Vegetation of Europe: Hierarchical floristic classification system of vascular plant, bryophyte, lichen, and algal communities. Applied Vegetation Science, 19(1), 3-264.

Naqinezhad, A. (2012). A physiognomic-ecological vegetation mapping of Boujagh National Park, the first marine-land National Park in Iran. Advances in Bioresearch, 3(1), 37-42.

Pedrotti, F. (2013). Plant and vegetation mapping. Springer-Verlag, Berlin Heidelberg.

Pobedimova, E. G. (1949a). Novyj vid roda Molinia Schrank na Ukraine [New species of the genus Molinia Schrank in Ukraine]. Botanicheskie Materialy Gerbarija Botanicheskogo Instituta AN SSSR, 11, 34-37 (in Russian).

Pobedimova, E. G. (1949b). Novye vidy roda Apocynum L. [New species of genus Apocynum L.]. Botanicheskie Materialy Gerbarija Botanicheskogo Instituta AN SSSR, 11, 130-133 (in Russian).

Pobedimova, E. G. (1952). Rod Trachomitum Woodson - Kendyr' [Genus Trachomitum Woodson-Kendyr]. Flora SSSR, 18, 654-657 (in Russian).

Ponomareva, A. A. (2015). Struktura i territorial'naja reprezentativnost' prirodnozapovednogo fondu Hersonskoj oblasti [Structure and territorial representativeness of the natural reserve fund of the Kherson region]. Magileyski Meridijan, 15(1-3), 41-44 (in Russian).

Pravotorov, I. A. (1967). K voprosu o transgressivnom hode urovnja za poslednie tysjacheletija na severnom lagunnom poberezh'e severo-zapadnoj chasti Chornogo morja [The question of the transgressive course of the last millennium on the northern lagoon coast of the northwestern part of the Black Sea]. Geologija poberezhja i dna Chjornogo i Azovskogo morej v predelah USSR. Kyiv University Press, Kyiv. Vol. 1. Pp. 33-41.

Roleček, J., Tichy, L., Zeleny, D., \& Chytry, M. (2009). Modified TWINSPAN classification in which the hierarchy respects cluster heterogeneity. Journal of Vegetation Science, 20, 596-602.

Sanda, V., Öllerer, K., \& Burlescu, P. (2008). Fitocenozele din România. Ars Docendi, Bucureşti [Phytocoenoses in Romania] (in Romanian).

Shaposhnikova, A. O. (2017a). Suchasnyj stan i aktual'ni naprjamky doslidzhen' roslynnosti NPP "Dzharylgac'kyj" [The current state and topical directions of vegetation research of National Nature Park "Dzharylgachsky"]. Chornomorski Botanical Journal, 13(2), 239-251 (in Ukrainian).

Shaposhnikova, A. O. (2017b). Synfitosozologichni doslidzhennja roslynnosti ostrova Dzharylgach [Synphytosozological investigation of vegetation of the island Dzharylgach]. Chornomorski Botanical Journal, 13(3), 278-294 (in Ukrainian).

Shaposhnikova, A. O., Boyko, M. F., Moysiyenko, I. I., Melnik, R. P., \& Ponomareva, A. A. (2015). Materialy do proektovanyh botanichnyh zakaznykiv (Hersons'ka oblast', Ukraina) [Materials for the projected botanical reserves (Kherson region, Ukraine)]. Chornomorski Botanical Journal, 11(3), 346-363 (in Ukrainian).

Solomakha, I. V., Shevchyk, V. L., \& Solomakha, V. A. (2017). Ogljad vyshhyh odynyc roslynnosti Ukrajiny za metodom Braun-Blanke ta jih diagnostychni vydy [Review of the higher vegetation units and diagnostic species of Ukraine according to the Braun-Blanquet approach]. Phytosociocenter, Kyiv (in Ukrainian).

Tichy, L. (2002). JUICE, software for vegetation classification. Journal of Vegetation Science, 13, 451-453.

Tomlinson, P. B., \& Posluszny, U. (2001). Generic limits in the seagrass family Zosteraceae. Taxon, 50(2), 429-437.

Wang, G., Innes, J. L., Wu, S. W., Krzyzanowski, J., Yin, Y., Dai, S., Zhang, X., \& Liu, S. (2012). National park development in China: Conservation or commercialization? Ambio, 41, 247-261.

Weber, H. E., Moravec, J., \& Theurillat, J.-P. (2000). International code of phytosociological nomenclature. 3-rd edition. Journal of Vegetation Science, 11, 739-768.

Westoff, V., \& van der Maarel, E. (1973). The Braun-Blanquet approach. Handbook of vegetation science. Ordination and classification of communities. Hague, 5, 617-726.

Yena, A. V., \& Moysienko, I. I. (2007). Trachomitum venetum subsp. russanovii (Pobed.) Yena \& Moysienko, comb. \& stat. nov. Willdenowia, 37(2), 435. 